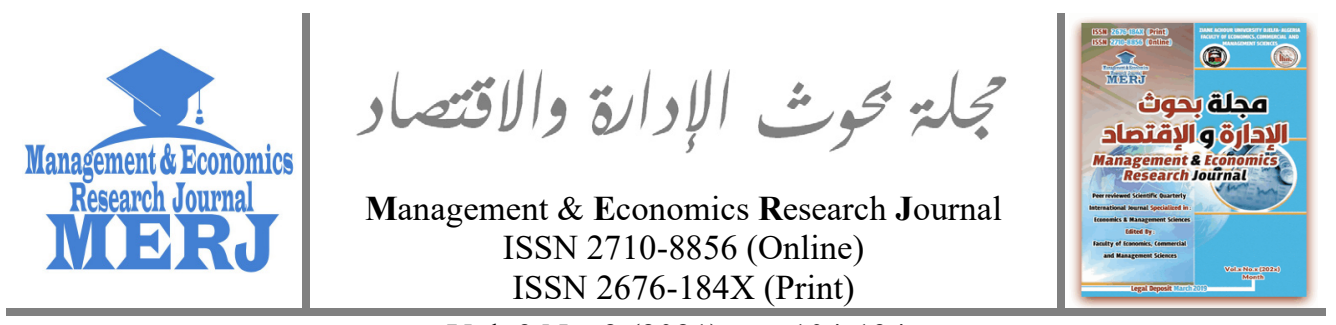

Vol. 3 No. 2 (2021), pp. 104-134

https://doi.org/10.48100/merj.2021.161

Check for updates

\title{
Debt, COVID-19 and Inclusive Growth for Sustainable Development in Sub-Saharan Africa
}

\author{
Bashir Olayinka Kolawole 1 \\ ${ }^{1}$ Senior Lecturer, Department of Economics, Lagos State University (Nigeria) \\ $\bowtie$ kolawolebashir@gmail.com
}

\begin{tabular}{lll}
\hline Received: 20-03-2021 & Accepted: 01-05-2021 & Published online: 03-05-2021 \\
\hline
\end{tabular}

\section{How to Cite:}

Kolawole, B. O. (2021). Debt, COVID-19 and Inclusive Growth for Sustainable Development in SubSaharan Africa. Management \& Economics Research Journal, 3(2), 104-134, https://doi.org/10.48100/merj.2021.161

\section{Abstract:}

The socioeconomic crisis associated with COVID-19 threatens progress toward attaining sustainable development goals. In this regard, global GDP will contract in 2020 by $5.2 \%$ against $2.8 \%$ in SSA. In addition, as the global recession is imminent, developing countries stand to accommodate about 60 million people into extreme poverty amid rising debt. However, as an indispensable requirement for sustainable development, United Nations and African Union resolve to eradicate extreme poverty through aspirations for inclusive growth by 2030 and 2063, respectively. Based on this background, this paper examines the impact of debt and COVID-19 and the effectiveness of growth inclusiveness for sustainable development in SSA. Imperatively, using a panel of 43 countries over the period 2016-2019, it is established that the level of employment increases just as life expectancy improves, in tandem with inclusive growth.

•Corresponding author: Department of Economics, Lagos State University (Nigeria).

[ $\square$ kolawolebashir@gmail.com]

(C)2021 the Author(s). This is an open-access article distributed under the terms of (CC BY-NC 4.0) which permits use, distribution and reproduction in any medium, provided the original work is properly cited and is not used for commercial purposes. 
Also, the timeline analysis of the COVID-19 period reveals that the unemployment rate and public debt are increasing substantially above the levels before the outbreak, thereby portending a setback on the gains achieved towards sustainable development in the region. As such, total debt cancellation is suggested, along with more financial assistance to economies in the region.

Keywords: COVID-19, Debt, Employment, Inclusive Growth, Sustainable Development.

JEL Codes: E60, H50, O10, O47, R11, R58.

\section{Introduction}

The devastating impact of coronavirus disease 2019 (COVID-19) on the global economy is evident in the spate of job loss, trade restrictions, and deaths across countries. Imperatively, global gross domestic product (GDP) is envisioned to contract by $5.2 \%$ in 2020 ; and by $8 \%$ in the same year if businesses cannot service debt. Sub-Saharan Africa (SSA) is to experience $2.8 \%{ }^{1}$ slow growth. ${ }^{2}$ Thus, considering the likely long duration of the crisis, coupled with spill-over effects from tighter global financial restrictions and recession, vulnerable developing countries stand to confront years of economic hardship. ${ }^{3}$ An estimated 60 million people in developing countries are expected to be pushed into extreme poverty, while years of progress toward development goals might be reversed (Mahler, Lakner, Aguilar \& Wu, 2020; World Bank, 2020a). However, African Union [AU] (2014) recognizes eradication of extreme poverty as an indispensable requirement for sustainable development and thus aspires for a prosperous Africa based on inclusive growth by 2063. Moreover, AU (2014) foresees an Africa where development is people-driven and youth potential is unleashed. To this end, AU aspires that by 2063, African youth will be engaged and empowered, as youth will have the guarantee of full access to education, training, and economic opportunities; and will contribute significantly to

\footnotetext{
${ }^{1}$ Also, by envisioning substantial growth downgrade of $0.5 \%$ in East Asia and the Pacific, $2.7 \%$ in South Asia, 4.2\% in the Middle East and North Africa, 4.7\% in Europe and Central Asia, and 7.2\% in Latin America, deepest recession in decades is imminent (World Bank, 2020a).

${ }^{2}$ See World Bank (2020a). Meanwhile, African Development Bank [AfDB] (2020) projects Africa's real GDP to accelerate from an estimated $3.4 \%$ in 2019 to $3.9 \%$ in 2020 and further to $4.1 \%$ in 2021 with Benin, Cote d'Ivoire, Ghana, Ethiopia, Rwanda, and Tanzania leading the way among the world's 10 fastest growers.

${ }^{3}$ See Goldberg and Reed (2020) and International Monetary Fund [IMF] (2020a) for shocks to activities.
} 
\begin{tabular}{l|l||l} 
Management \& Economics Research Journal & Vol. 3 No. $2(2021)$ & pp. 104-134 \\
\hline
\end{tabular}

innovation and entrepreneurship.

Meanwhile, the United Nations [UN] (2015) is on the verge of achieving its resolutions ${ }^{4}$ following a modest improvement in growth as necessitated by the mild rise in commodity prices, ${ }^{5}$ external demand, and increased agricultural production across countries in SSA. Also, there is relatively improved stability in social and political activities with a commendable reduction in security threats across countries, thereby setting the ground for a promising business environment. However, then, a high annual population growth rate of 3\% appears threatening given the slow GDP growth of $2.37 \%$ in 2018 from 2.52\% in 2017 (World Bank, 2019) as the average debt-to-GDP ratio set to rise to $64.8 \%$ of GDP in 2020 (IMF, 2020c). This, in effect, spells a negative per capita growth and a drag on the developmental efforts in the region. Moreover, growth has been less than inclusive in Africa ${ }^{6}$ as World Economic Forum [WEF] (2018) frowns at the poor performance of SSA countries in the Inclusive Development Index (IDI) ranking where among emerging economies, Tanzania ranks 48 and comes top in the region with IDI score of 3.43. The next in SSA is Ghana, with an overall rank of 52; Nigeria ranks 63; South Africa 69; Mozambique 74. Thus, given AU's aspirations and UN resolutions for inclusive growth, employment, and life expectancy, what drives inclusive growth in SSA?

Moreover, is growth inclusiveness effective for extending the region's life expectancy and productive employment? Nonetheless, is inclusive, sustainable development feasible beyond COVID-19 as debt levels stand to increase across the board in SSA? On this premise, this paper examines the impacts of debt and COVID-19 on inclusive growth and the effectiveness of inclusive growth for sustainable development in SSA.

Imperatively, there have been discussions on inclusive growth. Substantial aspects of the discussions, however, focus on attaining inclusiveness as an end through specific theoretical determinants of growth. For example, while Whajah, Bokpin, and Kuttu (2019) affirm that public

\footnotetext{
4 The resolutions include creating conditions for sustainable, inclusive, and sustained economic growth, full and productive employment, and decent work for all; to ending poverty and hunger; combating inequalities; building peaceful, just, and inclusive societies; protecting human rights and promoting gender equality by empowering women and girls, ensure the protection of the planet and its natural resources, and create conditions for shared prosperity and decent work for all.

${ }^{5}$ The rise in commodity prices favors Angola, Nigeria, and South Africa, who contributing about $60 \%$ of SSA's economic output. However, economies such as Benin, Cote d'Ivoire, Kenya, Rwanda, and Uganda that are not dependent on commodities have grown steadily and strongly (Toussaint, 2019).

${ }^{6}$ According to AfDB (2020), this is despite solid growth performance in which only about a third of countries on the continent achieved inclusive growth.
} 
debt exerts a negative effect on inclusive growth in Africa, Oyinlola, Adedeji, Bolarinwa, and Olabisi (2020) assert that growth inclusiveness would be a reality in SSA provided there is a reliable tax reform alongside quality governance. However, achieving growth inclusiveness is one thing; the other is whether such growth can lead to sustainable development. This follows from the fact that growth is insufficient for raising living standards (Collier, 2007; WEF, 2018). Thus, further research on the potential of inclusive growth leading to sustainable development is necessitated. Further research on the potential of inclusive growth in sustainable development will reveal the extent to which life expectancy can be lifted and how productive employment can be generated in SSA.

Moreover, extant discussions are raging on the devastating impact of COVID-19 on global economies. A considerable part of the discussions, however, concentrate on SSA, among which Mahler, Lakner, Aguilar, and $\mathrm{Wu}$ (2020) suggest that the region might be hit hardest as the Economic Commission for Africa [ECA] (2020) sees economic damage as unavoidable even if the spread of the pandemic is suppressed in Africa. This submission incidentally follows that the COVID-19 effect has caused a drop in Africa's exports as, apart from significant products, including textiles, the international price of oil has crashed by half. In contrast, tourism and the airline sector have suspended operations. As such, considering the desire for African countries to be among the best performers in the globally best quality of life measures and end all preventable deaths, it is pertinent to contribute to the discussions on the threat COVID-19 poses to achieving sustainable development in SSA. This paper's contribution will significantly proffer policy response to mitigating the impact of COVID-19 on sustainable development in the region.

The remaining aspect of the paper is structured as follows. The second section presents efforts toward sustainable development and a preCOVID-19 environment in SSA. Section three reviews relevant literature and section four provides the methodology. While empirical results are presented and discussed in section five, section six wraps the paper with a conclusion and policy implications.

\section{Efforts towards sustainable development and pre-COVID-19 environment in SSA}

In the attempt to build upon the achievements and address unfinished business of the Millennium Development Goals (MDGs), the heads of state and government and high representatives at its 70th-anniversary meeting in September 2015 decided on the new global Sustainable Development Goals 
\begin{tabular}{l|l|l} 
Management \& Economics Research Journal & Vol. 3 No. 2 (2021) & pp. 104-134 \\
\hline
\end{tabular}

(SDGs). ${ }^{7}$ Amongst the resolutions of the meeting is to create, between the day of the meeting and 2030, conditions for sustainable, inclusive, and sustained economic growth, full and productive employment, and decent work for all. In effect, per capita economic growth is to be sustained with at least 7\% GDP growth per annum and promoting entrepreneurship, among others.

Table 1. The pre-COVID-19 macroeconomic environment in selected SSA countries

\begin{tabular}{lllllll}
\hline Country & GDP & Population & Employment to & Life & Export & Impor \\
\hline Angola & -1.4 & 3.3 & 72.0 & 60.2 & 34.5 & 24.8 \\
Benin & 5.7 & 2.7 & 69.0 & 61.0 & 28.0 & 33.6 \\
Burkina Faso & 6.2 & 2.9 & 62.4 & 61.0 & 27.0 & 32.3 \\
Cape Verde & 4.7 & 1.2 & 53.0 & 72.4 & 47.6 & 65.2 \\
Chad & -0.9 & 3.1 & 69.5 & 53.5 & 33.3 & 38.1 \\
Comoros & 3.3 & 2.3 & 41.2 & 64.0 & 12.2 & 28.4 \\
Congo Rep. & -0.9 & 2.6 & 63.0 & 64.0 & 83.1 & 60.2 \\
Equatorial Guinea & -6.6 & 3.7 & 58.0 & 58.0 & 56.1 & 45.7 \\
Eswatini & 1.9 & 0.9 & 40.4 & 58.4 & 41.8 & 43.3 \\
Gambia & 4.8 & 3.0 & 54.0 & 61.3 & 20.5 & 39.1 \\
Guinea Bissau & 5.2 & 2.5 & 70.1 & 57.8 & 25.8 & 32.6 \\
Lesotho & 1.2 & 0.8 & 51.6 & 53.0 & 46.0 & 90.7 \\
Liberia & -0.1 & 2.5 & 74.2 & 63.2 & 25.1 & 98.0 \\
Mali & 5.2 & 3.0 & 65.7 & 58.3 & 23.3 & 36.4 \\
Mozambique & 3.3 & 3.0 & 75.8 & 59.4 & 39.5 & 73.0 \\
Namibia & -0.2 & 1.9 & 47.0 & 63.0 & 35.3 & 50.5 \\
Niger & 5.9 & 3.8 & 72.0 & 61.7 & 12.0 & 26.3 \\
Rwanda & 7.0 & 2.6 & 82.8 & 68.2 & 18.2 & 30.4 \\
Sao Tome \& Principe & 3.3 & 1.9 & 50.5 & 70.0 & 78.5 & 60.3 \\
Sierra Leone & 4.8 & 2.1 & 55.4 & 54.0 & 21.5 & 45.2 \\
Tanzania & 6.2 & 3.0 & 82.0 & 64.6 & 15.4 & 17.5 \\
Togo & 5.0 & 2.5 & 76.2 & 60.5 & 32.3 & 45.3 \\
Uganda & 5.3 & 3.7 & 69.2 & 62.4 & 15.9 & 21.9 \\
Zimbabwe & 0.6 & 1.5 & 78.9 & 60.8 & 19.4 & 40.0 \\
\hline
\end{tabular}

Source: Author's collation from World Bank (2020b)

Also, in an earlier resolution, the AU, through Agenda 2063, aspires for a prosperous Africa based on inclusive growth and sustainable development. $^{8}$ The resolution seeks that, by 2063, through strategies for inclusive growth, job creation, youth empowerment, and education, African

\footnotetext{
${ }^{7}$ According to the UN (2015), the integrated and indivisible SDGs are 17 with 169 associated targets. ${ }^{8}$ According to AU (2014), this is the first of the seven aspirations of Agenda 2063. Other aspirations are: an integrated continent, politically united and based on the ideals of Pan-Africanism and the vision of the Africa Renaissance; an Africa of good governance, democracy, respect for human rights, justice, and the rule of law; a peaceful and secure Africa; an Africa with a strong cultural identity, common heritage, values and ethics; an Africa where development is people-driven, unleashing the potential of its women and youth; and Africa as strong, united and influential global player and partner.
} 
countries will be amongst the best performers in global quality of life measures.

Furthermore, to achieve universal health coverage and access to quality health care, the UN's (2015) agenda is to promote physical and mental health and well-being, extend life expectancy, and end all preventable deaths by 2030. In so doing, it looks at accelerating progress in fighting malaria, Ebola, and other infectious diseases and epidemics affecting developing countries. In effect, the efforts impressed several regional economies such that GDP growth averaged 7\% in Rwanda. In comparison, life expectancy reached around $72 \%$ in Sao Tome \& Principe, as presented in Table 1. However, in a sudden twist to the progress made so far in achieving the development goals, the novel COVID-19 crisis surfaced as a huge threat to the global economy.

Meanwhile, through its inclusive and sustainable growth strategy, United Nations Development Programme [UNDP] (2017) recognizes the ambitious and collective efforts put into sustainable development. Otherwise referred to as an expanded vision of development, the idea is a vision and, according to UNDP, it captivates both the citizens and politicians. Essentially, the vision is balanced with regard to economic, social, and environmental dimensions. Accordingly, it requires fundamental changes in the pattern of economic growth in many economies where growth has never been socially and environmentally inclusive. To make the unprecedented vision a reality, UNDP identifies and offers three critical priorities to countries. The priorities include integrated planning for inclusive and sustainable growth; supporting employment creation, decent work, and distributive programs to address poverty, inequality, and exclusion; and mobilizing and scaling up financing to enable the transition to sustainable, inclusive growth. The agency, however, notes that given countries' different capacities and national priorities, the strategy might not provide a one-sizefits-all solution. Nonetheless, through its policy action on inclusive growth, Organization for Economic Co-operation and Development [OECD] (2018) also shows concern by recommending three principles to governments on sustaining and ensuring equitable distribution of the benefits from economic growth. The broad recommendations include the following:

- Investing in people and places.

- Supporting business dynamism and inclusive labour markets.

- Building efficient and responsive governments. 
\begin{tabular}{l|l||l} 
Management \& Economics Research Journal & Vol. 3 No. $2(2021)$ & pp. 104-134 \\
\hline
\end{tabular}

\section{Literature review}

\subsection{Theoretical framework and conceptual underpinning}

The theoretical framework stems from the fact that economic growth, and its sustainability, are a precursor to inclusive growth, as growth inclusiveness is fundamental to development. However, an essential factor required in the development process is the stock of capital which comprises facilities like schools, hospitals, and other public works necessary for societies to function (Srinivasu \& Rao, 2013). Imperatively, the stock of these facilities helps improve economic growth, per capita productivity, and individual well-being and are essential drivers of sustainable development (Ncube, Lufumpa \& Kararach, 2017). Thus, as sustainable development implies meeting the needs of the present generation without compromising the needs of the future generation, the stock of overall capital assets must remain constant or rise over time. Therefore, besides increased growth and provision of basic needs, lifting the standard of living also involves:

- better health and education opportunities for the people,

- participation in public life in a clean environment, and

- advocating intergenerational parity.

More so, where economic growth is achieved, it should be followed by productive employment. As such, in a basic Cobb-Douglas production function of the form $Y=f(K, L), Y$ is output or economic growth, and $\mathrm{K}$ is physical capital stock. L is human capital/labour or employment; the framework follows Thorbecke (2014) and Vellala, Madala and Chattopadhyay (2014), such that if $\mathrm{Y}$ is sustained, its benefits can be distributed to the people. However, to increase $\mathrm{Y}$, other growth drivers can be included altogether or in a one-after-the-other fashion.

Imperatively, future growth and overall quality of life are critically dependent on the quality of the environment. Therefore, as an agenda that focuses on a strong institution, a robust, inclusive growth strategy is prolabour and pro-business and is meant to boost economic efficiency and social inclusion (WEF, 2017). Accordingly, as a concept, UNDP (2017) asserts that inclusive growth has broadened discussion beyond only extreme poverty. Thus, AfDB (2013) refers to inclusive growth as economic growth that results in complete access to sustainable socioeconomic opportunities for a broader number of people, regions or countries with protection for the vulnerable in an environment of fairness, equal justice, and political plurality. Also, it connotes improvement in production, income generation and distribution (Suryanarayana, 2013). The process leading to inclusive 
growth involves getting employed, receiving income and engaging in consumption expenditure. However, being different from the standard and approaches to economic growth, the Catholic Agency for Overseas Development [CAFOD] (2014) sees inclusive growth as more than outcome and income, but participation in economic activities with a beneficial reduction in poverty and inequality. It requires strong institutions, human capital development and employment generation, enhanced productivity through modern technology, welfare-improving redistributive policies, indiscriminative participation and social protection (Kolawole, 2016). Similarly, Duraiappah (2015) affirms that inclusive growth reduces income inequality.

\subsection{Empirics on inclusive growth}

The literature is vast on growth empirics; however, the relevant ones are scanty. Thus, in a country-based study, Kolawole (2016) investigates the relationship between inclusive growth and government spending in Nigeria from 1995 to 2014. While growth inclusiveness is measured by GDP per capita, the Autoregressive Distributed Lag (ARDL) technique reveals that as real GDP growth propels inclusion in both the short- and long-run, government spending instead causes inclusion only in the long run. The study thus concludes that government redistributive spending on health has a significant positive relationship with inclusive growth in the country. However, Oosthuizen and Cassim (2016) explore the relationship between informality and inclusive growth in SSA. On the assumption that South Africa has relatively high levels of unemployment with low informal employment, the study hypothesizes whether or not the informal labour market promotes or constrains inclusive growth. Findings reveal that where unemployed people are self-employed and not in a precarious situation of ill health and insecurity, the informal sector promotes inclusive growth, though at the expense of the agricultural sector. As such, for being a significant employer of labour and a contributor to SSA's economies, firms in the informal sector should be provided with access to credit, energy and space to grow and prosper.

Moreover, in a study that examines the relationship linking government size, public debt and inclusive growth in Africa, Whajah, Bokpin, and Kuttu (2019) employ a fixed-effect method to estimate a panel of 54 countries for the period 2000-2016. While finding a positive relationship between government size and inclusive growth, the result further establishes that public debt negatively impacts inclusive growth. Thus, the study suggests necessary steps to make growth more inclusive and 
\begin{tabular}{l|l|l} 
Management \& Economics Research Journal & Vol. 3 No. 2(2021) & pp. 104-134 \\
\hline
\end{tabular}

the need for government to maintain the optimal level of public debt. More so, in another study that explores the Generalized difference Method of Moments (GMM), Oyinlola et al. (2020) investigate the role of governance in the resource mobilization-inclusive growth relationship in 27 SSA countries over the period from 1995 to 2015 . The result shows that the persistence level of inclusive growth largely determines growth inclusiveness, Using aggregate and disaggregated taxes as indicators of domestic resource mobilization. However, as both taxes have no significant effect, all governance dimensions positively impact inclusive growth. It is therefore suggested that for growth inclusiveness to be a reality in SSA, reliable tax reform should be developed along with quality governance.

\subsection{Empirics on COVID-19}

As the U.S. economy sets for reopening following the confirmation of a decline in COVID-19 cases and death in the country's North-eastern states, Baqaee, Farhi, Mina and Stock (2020) examine the policies to avert death-related economic consequences in the second wave. Thus, using the five-age epidemiological model and 66-sector economic accounting, the study finds that shutdown is not potent enough to stop a second wave. Instead, while hoping for economic recovery, a second wave can be averted if social restrictions are reintroduced along with personal distancing, wearing of masks, protecting older adults and other vulnerable, and increasing testing and quarantine.

Furthermore, as some firms expand in response to pandemic-induced demand shifts amid the shrinking U.S. economy, Barrero, Bloom and Davis (2020) draw on firm-level forecasts at a one-year horizon in the Survey of Business Uncertainty (SBU) to confirm that COVID-19 is also a reallocation shock. By constructing new reallocation measures for jobs and sales, the study finds the measures rising sharply by 3.9 times between February and April 2020, more than the pre-COVID-19 average for jobs (sales). Also, the study draws on particular SBU questions to test the hypotheses that, given the pandemic's shock, three new hires will occur for ten layoffs. Also, while some layoffs will be permanent, one out of 10 workdays will be used for residential premises after the pandemic. Incidentally, across firms, the study confirms an increased vacancy, overall employment and formation of new firms, and an improved varying degree of stock performance. Afterwards, the implications for the economic outlook and policy responses to the pandemic are considered. Consequently, the study submits that unemployment benefit levels that exceed worker earnings, policies that subsidize employee retention, land-use restrictions, 
occupational licensing restrictions, and regulatory barriers to business formation will impede reallocation responses to the COVID-19 shock.

Moreover, following the impact of the COVID-19 crisis on lowincome families in the U.S., Bitler, Hoynes and Schanzenbach (2020) examine the social safety net in place in the wake of the pandemic. While the study recognizes that the Supplemental Nutrition Assistance Program (SNAP) payments could respond quickly to the increasing need, the benefits are modest. However, the study notes that the counter-cyclical impact of SNAP could be dampened if the policy that makes it cumbersome for immigrants to participate is not waived. The study recommends that many social nets be extended and adapted to the ongoing crisis. Also, the unemployed insurance (UI) system should be redesigned to reach a more significant percentage of disadvantaged unemployed workers. In addition, more automatic stabilizers should be put in place to ameliorate the impact of the rising unemployment rate.

Moreover, while providing a preliminary account of the effects of the Coronavirus pandemic in emerging markets and developing economies, Goldberg and Reed (2020) find that, so far, developing countries are faring relatively well in public health consequences. On the economic side, however, despite affirming encouraging signs regarding the short-term economic recovery of several countries, the study yet sounds cautious that it is premature to predict the medium- and long-term effects of the crisis. In conclusion, the study holds the view that considering the heterogeneous effects of the crisis on specific countries in both the short- and long-run, there is optimism that non-energy-reliant and non-metal export-dependent countries could recover quickly. Nonetheless, as the resulting pattern is attributed to the younger population, the study claims that most low- and middle-income countries experience significantly lower deaths than highincome countries.

Meanwhile, in an attempt to address the economic impact of the COVID-19 pandemic, Han, Meyer and Sullivan (2020) provide timely information on the impact of the pandemic on income and poverty to inform the targeting of resources to those most affected and assess the success of current efforts. By using high-frequency data on the income of a large representative sample of U.S. families, the study constructs measures of income distribution and poverty with a lag of only a few weeks. The results show that at the start of the pandemic, government policy effectively mitigates its effects on incomes, leading poverty to fall and low percentiles of income to rise across various demographic groups and geographies. Thus, the decline in poverty could be ascribed to the rise in government assistance, 
\begin{tabular}{l|l|l} 
Management \& Economics Research Journal & Vol. 3 No. 2 (2021) & pp. 104-134 \\
\hline
\end{tabular}

including unemployment insurance benefits and economic impact payments.

\subsection{COVID-19 experience in SSA}

Following the report of COVID-19 spread from person to person in the latter part of November 2019, the disease has declared a pandemic in March 2020 (Secon, 2020). In effect, the tabular presentations in Appendices A, B, C and D show that by March 31, the virus had spread across SSA with 1,380 cases and five deaths in South Africa; Burkina Faso with 261 cases and 14 deaths. Cameroon with 233 cases and six deaths; Ghana with 195 cases and five deaths; Mauritius recorded 158 cases and five deaths; and Nigeria had 151 cases with two deaths, among others. Moreover, as Malawi announced a 21-day lockdown, Uganda extended the lockdown and ban on public transportation until May 5. Also, Guinea, Kenya, South Africa and Zimbabwe, among other countries, announced mandatory wearing of masks in public and widespread mass testing. Incidentally, on April 16, the African Union's Africa Centre for Disease Control and Prevention (Africa CDC) planned to distribute one million testing kits across the continent. Botswana and Cameroon announced a commendable number of prisoners released in sentence reduction and/or outright pardon as a complementary measure. Also, IMF provided debt relief to 19 countries in the region, thereby making it convenient for the countries to divert financial resources to fight the pandemic. In addition, aside from financial assistance provided to address unanticipated financing needs resulting from the pandemic, yet poorest countries in the region were considered to benefit from the one-year debt repayments suspension agreed to by the G20 forum. Imperatively, the COVID-19 crisis awakened reality to the importance of telecommunications. Mobile money and other digital payment systems were used and encouraged as a means of the transaction while keeping social distance. In effect, governments could make a cash transfer to the supposedly poorest of the poor and provide information on the pandemic.

Nonetheless, by the end of April, even while countries which included Cameroon, Mauritius, Niger, Rwanda, and South Africa gradually eased restrictions (IMF, 2020c), yet, as presented in Appendix B, the number of COVID-19 deaths in South Africa increased to 103 with 5,647 cases. Also, in April, Cameroon recorded 1,832 cases with 61 deaths as against 1,932 cases and 58 deaths in Nigeria; 719 cases with 32 deaths in Niger; Burkina Faso showed 641 cases and 43 deaths; Democratic Republic of Congo (DRC) recorded 31 deaths with 572 cases; Kenya with 411 cases and 21 deaths; with Sudan having 31 deaths and 442 cases. Thus, it became 
challenging to combat the pandemic as access to health care was limited, most people could not access clean water to wash their hands regularly, and workers kept losing their jobs. At the same time, households could not obey stay-at-home orders for a lack of food and basic income.

Unfortunately, the pandemic soared significantly by May 31 as 705 deaths were recorded, with 34,357 cases in South Africa. In addition, the number of deaths reached 287 with 10,162 cases in Nigeria; Ghana had 36 deaths and 8,070 cases; Cameroon recorded 6,143 cases with 197 deaths; Sudan reported 286 deaths and 5,026 cases, and 69 deaths were experienced in Kenya with 2,021 cases. Meanwhile, as the pandemic raged, by June 30, zero death was recorded in Namibia and Uganda, among several other countries. However, death increased in certain countries, which included South Africa with 2,657 deaths and 151,209 cases, followed by Nigeria with 590 deaths and 25,694 cases; Cameroon with 12,592 cases and 313 deaths; and Sudan with 572 deaths and 9,257 cases. Moreover, while countries set to reopen economies, the fear of the (second wave) became obvious as response measures were reviewed. In this regard, following an additional one week to the second phase of the gradual easing of the lockdown in Nigeria, Kenya announced a month extension, with effect from July 27. However, at the lapse of the week-long extension, Nigeria further extended the second phase ease of lockdown by four weeks. Also, while Zimbabwe extended by one month, Gambia declared a national emergency on COVID19 and announced a night curfew for 21 days. Thus, by the end of July, the number of confirmed cases rose to 493,183 in South Africa, with 8,005 deaths against 879 and 107 deaths in Nigeria and Madagascar, respectively. Nonetheless, despite increasing cases of the pandemic amid shrinking economies across the region, the first week of September saw countries opening for international flights. Incidentally, South Africa recorded over one million cases by December, with more than 28,000 deaths.

\section{Methodology}

Two periods are considered to examine the impact of COVID-19 and the effectiveness of inclusive growth for sustainable development in the SSA. The first period, 2016-2019, is the era before COVID-19, in which the starting year coincides with the commencement of the SDGs. The period is important to appraise economic performance resulting from the SDGs' introduction and implementation and evaluate the economic situation before the advent of COVID-19. The second period is the pandemic era, in which the economic crisis resulting from the virus emerges. Thus, the second period is necessary for the appraisal and analysis of the impact of debt and 
\begin{tabular}{l|l||l} 
Management \& Economics Research Journal & Vol. 3 No. 2 (2021) & pp. 104-134 \\
\hline
\end{tabular}

COVID-19 on per capita economic growth and the need to fashion ways to revamp economies towards achieving the SDGs after the pandemic. As such, in the attempt to address the objectives of the first period, the panel data econometric technique is adopted to estimate three different equations; the first equation expresses the relationship linking inclusive growth and its determinants prior to COVID-19, the second equation specifies the effect of inclusive growth on life expectancy, while the third equation assesses the effect of inclusive growth on productive employment. On the other hand, the timeline or situation analysis method is used to analyze the macroeconomic environment in the second period.

Meanwhile, because SSA countries are the least ranked on the inclusion index among emerging economies, coupled with data constraints, 43 countries $^{9}$ are considered in the region. Very imperative is the fact that policymakers appraise economic success by GDP growth. However, the reality is that most households do not evaluate economic progress by the GDP growth rate but by changes in their standard of living (WEF, 2018). As an alternative to GDP for evaluating countries' economic progress, the IDI suffices as a measure. Nevertheless, then, due to the non-availability of IDI data for the sampled countries over the period considered, and following the exposition of Thorbecke (2014), as well as the empirical work of Oyinlola et al. (2020), GDP per person employed is used as a measure of inclusive growth. However, data for GDP per person employed, per capita income, life expectancy, the business extent of disclosure index, external debt, foreign direct investment, and official development assistance are transformed from nominal to natural logarithms in order to obtain a uniform scale of measurement and to simplify the interpretation of estimation coefficients.

\subsection{The models}

Imperatively, the key drivers of inclusive growth include productive employment, human development factors, socioeconomic amenities, and economic growth (Vellala et al., 2014). Therefore, following Barro (1991), Thorbecke (2014), and Vellala et al. (2014), the functional specification of

\footnotetext{
9 The countries are Angola, Benin, Botswana, Burkina Faso, Burundi, Cameroon, Cape Verde, Central Africa Republic, Chad, Comoros, Congo DC, Congo Republic, Cote d'Ivoire, Equatorial Guinea, Ethiopia, Eswatini, Gabon, Gambia, Ghana, Guinea, Guinea Bissau, Kenya, Lesotho, Liberia, Madagascar, Malawi, Mali, Mauritius, Mozambique, Namibia, Niger, Nigeria, Rwanda, Sao Tome \& Principe, Senegal, Sierra Leone, South Africa, Sudan, Tanzania, Togo, Uganda, Zambia, and Zimbabwe.
} 
the relationship linking inclusive growth with per capita income, Pci, population growth rate, Popg, employment, Emp, life expectancy, Lfx, economic growth, Grt, capital formation, Gfcf, entrepreneurship, Ent, and other macroeconomic determinants, $\mathrm{X}$, is stated as:

$$
\text { inG } G_{i t}=f\left(\text { Pci }_{i t}, \text { Popg }_{i t}, \text { Emp }_{i t}, \text { Lfx }_{i t}, \text { Grt }_{i t}, \text { Gfcf }_{\text {it }}, \text { Ent }_{i t}, X_{\text {it }}\right)
$$

And follows Baltagi (2008) in a general form,

$\operatorname{inG}_{i t}=\beta_{0}+\beta_{1} X_{i t}^{\prime}+u_{i}+v_{i t} i=1, \ldots, 43 ; t=2016, \ldots, 2019$.

Where, for country $i$ at time $t$, inG is inclusive growth proxy by the natural logarithm of GDP per person employed and measured in constant 2017 purchasing power parity (PPP) dollar. $\beta_{0}$ is the constant intercept, $\beta_{1}$ is $\mathrm{Kx} 1$ as $\mathrm{X}^{\prime}$ is $1 \mathrm{xK}$, a vector of time-variant independent variables, $\mathrm{u}$ is a time-invariant unobservable country-specific fixed effect, and $v$ represents other time-variant disturbances that are independently and identically distributed.

Moreover, as the principal goal of development policy, sustainable development aims at creating sustainable improvements in the quality of life for all people. Therefore, growth inclusiveness should improve life expectancy and productive employment, respectively, as follows:

$$
\begin{aligned}
& \mathrm{Lfx}_{\mathrm{it}}=\beta_{0}+\beta_{1} \mathrm{inG}_{\mathrm{it}}+\beta_{2} \mathrm{X}_{\mathrm{it}}^{\prime}+\mathrm{u}_{\mathrm{i}}+\mathrm{v}_{\mathrm{it}} \\
& \mathrm{Emp}_{\mathrm{it}}=\beta_{0}+\beta_{1} \mathrm{inG}_{\mathrm{it}}+\beta_{2} \mathrm{X}_{\mathrm{it}}^{\prime}+\mathrm{u}_{\mathrm{i}}+\mathrm{v}_{\mathrm{it}}
\end{aligned}
$$

Where Lfxis (life expectancy at birth) and Empis (employment to population ratio) are measured as the proportion (\%) of a country's population that is employed.

\subsection{Estimation technique}

The estimation of each of the static models in (2), (3) and (4) is possible by applying Ordinary Least Squares (OLS), Fixed Effects (FE), Random Effects (RE), and GMM estimators (Olubusoye, Salisu \& Olofin, 2016). However, where the time dimension of the panel is small and fixed, OLS regression may result in heterogeneity bias and lead to biased and inconsistent estimates (Nickell, 1981; Judson \& Owen, 1999). Consequently, the coefficients of the explanatory variables would likely be 
\begin{tabular}{l|l|l} 
Management \& Economics Research Journal & Vol. 3 No. 2 (2021) & pp. 104-134 \\
\hline
\end{tabular}

subject to a downward bias towards zero in absolute terms. Also, given the potential to solve the endogeneity problem that might occur in this situation where $\mathrm{T}$ is small, and $\mathrm{N}$ is large, Green (2011) suggests the use of Arellano and Bover (1995) GMM, as well as Blundell and Bond (1998) systemGMM estimators. However, given the requirement of many instruments, the system-GMM is not applicable in this case. However, the results from the Hausman fixed and the Breusch and Pagan LM diagnostic tests can tell whether or not the Generalized Least Squares (GLS) technique is suitable. Essentially, the GLS allows for the country-specific intercept (that is, FE).

\section{Results and discussion}

\subsection{Descriptive statistics}

The descriptive statistics of all variables employed for estimation are presented in Table 2. The average per capita income, Pci, of US2286.9 dollars is encouraging, given the region's minimum value of US208.1 dollars. This portends the fact that the majority of countries across the continent are doing fairly well.

Table 2. Descriptive statistics

\begin{tabular}{llllll}
\hline Variable & Obs & Mean & Std. Dev & Min & Max \\
\hline Pci & 172 & 2286.9 & 2755.5 & 208.1 & 12358.3 \\
InG & 172 & 14313.5 & 15159.5 & 1764.5 & 68487.3 \\
Grt & 172 & 3.4 & 3.32 & -8.82 & 10.2 \\
Popg & 172 & 2.5 & 0.8 & 0.03 & 3.9 \\
Emp & 172 & 62.2 & 13.1 & 39.9 & 84.4 \\
Lfx & 172 & 62.1 & 4.9 & 51.6 & 74.5 \\
Gfcf & 172 & 23.6 & 8.9 & 7.8 & 52.6 \\
Ent & 172 & 1.6 & 0.5 & 0.0 & 2.3 \\
Xpt & 172 & 30.2 & 16.5 & 6.7 & 97.8 \\
Imp & 172 & 39.8 & 19.0 & 11.5 & 100.3 \\
Mchtrd & 172 & 49.8 & 23.8 & 17.0 & 144.8 \\
Xdbt & 172 & $1.29 \times 10^{10}$ & $2.69 \times 10^{10}$ & $1.69 \times 10^{8}$ & $1.80 \times 10^{11}$ \\
Tdbtsv & 172 & 2.6 & 3.1 & 0.2 & 20.6 \\
Fdi & 172 & $6.82 \times 10^{8}$ & $1.44 \times 10^{9}$ & $-7.40 \times 10^{9}$ & $5.57 \times 10^{9}$ \\
Oda & 172 & 61.7 & 43.6 & 4.0 & 231.5 \\
Agrva & 172 & 20.9 & 13.5 & 1.9 & 60.3 \\
Indva & 172 & 24.0 & 11.2 & 5.2 & 58.3 \\
Servva & 172 & 47.5 & 9.70 & 26.9 & 71.8 \\
\hline
\end{tabular}

Source: Author's computation

Although the average GDP per person employed, as a proxy for inclusive growth, inG, at about US14313 PPP dollars, is mild, it is promising given the level of development across economies. The two exciting factors that deserve special consideration are the annual GDP 
growth rate and the population growth rate in SSA. As shown in the Table, while the maximum GDP growth reached $10.2 \%$, population growth settled at an exploding level of $3.9 \%$. Nonetheless, the threat to sustainable development becomes obvious when the average values of the factors are considered, given that both are close to 3.4 and $2.5 \%$ for GDP growth and population growth, respectively.

Another threat for worry is the region's value for export and import; while export averaged $30.2 \%$, import shows a higher value at $39.8 \%$. This shows that the majority of countries in SSA import more than they export. However, another concern is the value addition, in terms of average, minimum and maximum, wherein the service sector has the highest figures, followed by industry. The performance in merchandise trade may explain that agriculture value-added is relatively the least compared to export and import in the region.

More so, the average of $62.1 \%$ for life expectancy can be improved upon if development efforts are further geared towards sustainability across economies in SSA. Imperatively, the employment ratio to the population gives a maximum of $84.4 \%$ against roughly $40 \%$ for minimum, with an average of $62.2 \%$. The average value shows that the majority of the population across SSA is employed.

\subsection{Correlation matrix}

The pattern of the relationships subsisting among the variables is presented in the correlation matrix in Table 3. The Table shows a general case of a fairly strong correlation among the exogenous variables.

Table 3. Abridged correlation matrix

\begin{tabular}{llllllllllll}
\hline & Pci & InG & Grt & Popg & Emp & Lfx & Gfcf & Xpt & Imp & Mchtrd & Xdbt \\
\hline Pci & 1 & & & & & & & & & & \\
InG & 0.976 & 1 & & & & & & & & \\
Grt & 0.414 & 0.398 & 1 & & & & & & & & \\
Popg & 0.521 & 0.284 & 0.048 & 1 & & & & & & \\
Emp & 0.463 & 0.573 & 0.204 & 0.321 & 1 & & & & & & \\
Lfx & 0.324 & 0.292 & 0.183 & 0.191 & 0.076 & 1 & & & & & \\
Gfcf & 0.127 & 0.109 & 0.304 & 0.125 & 0.012 & 0.207 & 1 & & & \\
Xpt & 0.413 & 0.381 & 0.309 & 0.223 & 0.289 & -0.214 & 0.186 & 1 & & & \\
Imp & 0.028 & 0.026 & 0.184 & 0.326 & 0.074 & -0.005 & 0.299 & 0.539 & 1 & & \\
Mchtrd & 0.306 & 0.267 & 0.319 & 0.304 & 0.274 & -0.069 & 0.143 & 0.651 & 0.641 & 1 & \\
Xdbt & 0.284 & 0.306 & 0.111 & 0.173 & 0.229 & -0.049 & 0.053 & 0.101 & 0.224 & 0.051 & 1 \\
\hline
\end{tabular}

Source: Author's computation 
\begin{tabular}{l|l|l} 
Management \& Economics Research Journal & Vol. 3 No. 2(2021) & pp. 104-134 \\
\hline
\end{tabular}

However, the matrix presents a situation where most variables are positively correlated; they move in the same direction and are appropriate when brought together in the respective models. Specifically, however, a negative correlation is represented between life expectancy on the one hand and each entrepreneurship, exports, imports, merchandise trade, and external debt in the region on the other. The situation notwithstanding, there appears to be no threat to the analysis as the affected variables are not employed together in the life expectancy model.

\subsection{Estimation results}

Following the probability values of 0.002 and 0.000 from the Hausman fixed and the Breusch and Pagan LM diagnostic tests result, the GLS technique is adopted for estimation. Thus, the results of the estimations of models (2), (3), and (4) are presented together in Table 4. As such, in model (2), the inclusive growth model, per capita income drives inclusive growth such that a $10 \%$-point rise in per capita income leads to a $9.6 \%$ inclusiveness in growth. However, population growth is a drag as growth inclusiveness slows by $0.07 \%$ from a $10 \%$-point increase. This corroborates the World Bank's 2019 forecast that economic growth will lag behind population growth and remain below the 2015 rate of 3\% (Toussaint, 2019). However, the higher the level of employment, the higher the inclusiveness of growth, as $0.2 \%$ growth appears inclusive given $10 \%$-point additional employment in the region. Also, as life expectancy from birth improves by $10 \%$, growth becomes inclusive substantially by $2.2 \%$. More so, as expected, additional stock of capital by $10 \%$-point generates inclusive growth mildly by $0.6 \%$ and buttresses the view of Balogun (2016) that an improved capital formation spurs socioeconomic growth and enhances the development process.

Further, in conformity with expectations, growth becomes more inclusive by $1.9 \%$ as entrepreneurial activities increase by $10 \%$. Imperatively, the role of entrepreneurship as the driving force of economic growth is rooted in Schumpeter's theory of long waves (UNCTAD, 2005). Moreover, there are suggestions that countries with high levels of entrepreneurship do not suffer low levels of economic growth. Although the association is significant, a unidirectional causal relationship runs from entrepreneurship to economic growth (Reynolds, William, Bygrave, Larry \& Michael, 2000, 2002; Harbi, Grolleau \& Bekir, 2011). Nonetheless, from empirical studies, Stam (2008) affirms mixed findings on entrepreneurship's role in economic growth. Unfortunately, importing goods and services drags growth inclusiveness backwards by a mild $0.1 \%$ despite a $10 \%$-point 
increase in imports. However, growth inclusiveness is propelled by $0.3 \%$ due to a 10\%-point improvement in the merchandise trade. Not surprisingly, external debt drags inclusive growth backwards by $0.2 \%$ due to a $10 \%$-point rise in foreign debt liability. Accordingly, the negative effect of debt corroborates Cecchetti, Mohanty and Zampolli (2010) and Kumar and Woo (2010) that in a period of declining revenue and rising expenditure, debt increases by setting back growth. The situation buttresses the World Bank's position that by the end of 2018 , almost $50 \%$ of SSA countries covered by the low-income country debt sustainability framework were as debtdistressed as more than twice the figure in 2013 (Toussaint, 2019). This corroborates IMF (2020b) that the high debt reflects borrowing by countries like Ethiopia and Kenya to finance investment in infrastructure. The average debt ratio in low-income developing countries reached $43 \%$ of GDP over 2017-2019. Meanwhile, a 10\%-point increase in agriculture value-added causes inclusiveness in growth by $1.1 \%$. Incidentally, a convincing case is made that agriculture is the only growth engine in most SSA countries (World Bank, 2007; OECD/FAO, 2016).

Furthermore, in THE model (3), the life expectancy model, per capita income positively impacts life expectancy as a $10 \%$-point rise in income causes a $2.8 \%$ improvement in life expectancy. Also, as growth becomes more inclusive by a $10 \%$-point, life expectancy improves by $3.2 \%$. However, life expectancy is threatened by an increase in the rate at which the population grows, given that a mild $0.2 \%$ drop in life expectancy from birth results from a $10 \%$-point addition to the population. This invariably supports Todaro and Smith (2003) that the problem of population growth is not simply of numbers but human welfare and development. Notwithstanding, as more percentage of the population gets employed, a further boost occurs to life expectancy. This situation follows from the fact that a $10 \%$-point increase in employment adds a $0.2 \%$ improvement to life expectancy.

Moreover, as the stock of capital increases by $10 \%$-point, life expectancy rises by $0.6 \%$. This probably reflects the mild contribution of medical facilities like hospitals, health centres, and the rest that provide basic health services to pregnant women and newly born children in SSA. The availability of primary health facilities and the provision of services go a long way in helping curb both infant and maternal mortality in the region.

Meanwhile, in model (4), the employment model, the employment level rises by $3.9 \%$ from a $10 \%$ point in addition to per capita income. A rise in population growth brings about a reduction in the ratio of employed persons to the population. The situation is described by a $10 \%$-point 
\begin{tabular}{l|l|l} 
Management \& Economics Research Journal & Vol. 3 No. 2 (2021) & pp. 104-134 \\
\hline
\end{tabular}

increase in population growth leading to a $0.4 \%$ fall in employment. This, no doubt, shows the effect of high and increasing population growth in the region where most economies are not expanding in tandem with the population explosion. By and large, going by the figures released by the National Bureau of Statistics (2020) and Trading Economics (2020), the impact of the bulging youth population and youth unemployment cannot be overlooked in this finding. Meanwhile, the finding buttresses the claim by Yalnizyan and Johal (2018) that the ageing population and demographic uncertainty cause economies to slow such that in the future, economic growth is expected to be half the rate of what it used to be 50 years back.

Table 4. Pre-COVID-19 inclusive growth, life expectancy, and employment in SSA

\begin{tabular}{|c|c|c|c|}
\hline Variable & $\begin{array}{l}\text { Inclusive growth } \\
\text { Model (2) }\end{array}$ & $\begin{array}{l}\text { Life expectancy } \\
\text { Model (3) }\end{array}$ & $\begin{array}{l}\text { Employment } \\
\text { Model (4) }\end{array}$ \\
\hline Per capita income & $(0.96)^{* * *}$ & $(0.29)^{* *}$ & $(0.39)^{* * *}$ \\
\hline Inclusive growth & - & $(0.32)^{* * *}$ & 0.11 \\
\hline Growth rate & $(0.02)$ & $(-0.01)$ & $(0.02)$ \\
\hline Population growth rate & $(-0.07)^{* *}$ & $(-0.02)^{* *}$ & $(-0.04)^{* *}$ \\
\hline Employment & $(0.02)^{* * *}$ & $(0.04)^{* *}$ & - \\
\hline Life expectancy & $(0.22)^{* * *}$ & - & 0.05 \\
\hline Capital formation & $(0.06)^{* *}$ & $(0.06)^{* *}$ & - \\
\hline Entrepreneurship & $(0.19)^{* * *}$ & - & $(0.41)^{* *}$ \\
\hline Export & $(0.08)^{*}$ & - & $(0.22)$ \\
\hline Import & $(-0.01)^{* *}$ & - & $(-0.02)^{* * *}$ \\
\hline Merchandise trade & $(0.03)^{* *}$ & - & $(0.06)^{* * *}$ \\
\hline External debt & $(-0.02)^{* * *}$ & - & $(0.01)^{* *}$ \\
\hline Total debt service & $(-0.03)$ & - & $(-0.31)$ \\
\hline Fdi inflow (net) & $(-0.01)$ & $(0.28)$ & $(0.02)$ \\
\hline Oda (net) & $(0.01)$ & $(0.03)$ & $(0.33)$ \\
\hline Agric value-added & $(0.11)^{* *}$ & $(0.44)$ & $(0.12)^{* *}$ \\
\hline Industry value-added & $(-0.02)$ & $(0.15)$ & $(-0.03)^{*}$ \\
\hline Service value-added & $(0.01)$ & $(0.02)$ & $(0.01)$ \\
\hline Adj. $R^{2}$ & 0.86 & 0.71 & 0.77 \\
\hline F-Statistic & 460.2 & 374.4 & 0.401 \\
\hline
\end{tabular}

Values in parentheses are coefficients, while $* * *, * *$, and $*$ imply $1 \%, 5 \%$, and $10 \%$ levels of significance, respectively. Statistical decisions are, however, based on a 5\% level.

Source: Author's computation

Meanwhile, importing goods and services reduces employment, giving a $0.2 \%$ drop in employment due to a $10 \%$-point increase in imports. On the contrary, merchandise trade helps raise employment, as $0.6 \%$ additional employment is created from a 10\%-point expansion in merchandise trade. Furthermore, agriculture value-added propels employment by $1.2 \%$ from a $10 \%$-point rise. The result, to a large extent, supports previous findings, which affirm that productivity in agriculture 
reflects a rise in the agricultural share of employment, leading to higher GDP per capita as experienced in Ghana, Botswana, and Liberia (Thorbecke, 2014). Also, the efficacy of agriculture for employment is emphasized by Filmer and Fox (2014), who suggest agriculture targeting as a policy priority for addressing youth unemployment in SSA. In addition, OECD/FAO (2016) has noted that agriculture's contributing role to food security is reflected in its prioritization in the development agenda. More importantly, entrepreneurship generates more employment as a 10\%-point increase in entrepreneurial activities creates a further $4.1 \%$ addition to employment. This affirms the notion that entrepreneurship is a sustainable tool for job creation in Africa, such that without adequate entrepreneurship development, the continent faces an uncertain future (Obonyo, 2016; Adegboye, 2018).

Very instructive, though mild, is the positive impact of external debt on employment in the region, given that $0.1 \%$ employment is generated from a $10 \%$-point increase in foreign debt obligation. The positive impact of debt largely supports the view of DeLong and Summers (2012) that a debtdriven expansionary policy propels growth and employment in the short run. As such, debt-driven employment in SSA could be ascribed to activities in economies that do not depend on regional commodities.

\section{Conclusion and policy implications}

This paper examines the impacts of debt and COVID-19 and the effectiveness of inclusive growth for sustainable development in SSA using the GLS technique. The pre-COVID-19 analyses reveal that the road to sustainable development is not rough but not very smooth either. This follows from the fact that although per capita income, entrepreneurship and agriculture, among others, can bring about inclusive growth, debt appears to be a formidable threat to sustainable development in the region. More so, sustainable development is feasible considering the roles of per capita income, employment, and growth inclusiveness in necessitating higher life expectancy. Furthermore, additional employment can be created effectively through entrepreneurship, agriculture, and merchandise trade.

Meanwhile, as confirmed cases of COVID-19 climb, revenue loss grows substantially amid rising public spending while the tax-to-GDP ratio increases across countries by an average of $3.7 \%$ of GDP. In this regard, interest on expenditure increases, resulting in high debt, currency depreciation, and a growing percentage of non-concessional borrowing. More so, the unemployment rate increased across SSA countries. For example, the rate increased in Angola and South Africa from 31.8 and 
\begin{tabular}{l|l||l} 
Management \& Economics Research Journal & Vol. 3 No. $2(2021)$ & pp. 104-134 \\
\hline
\end{tabular}

$29.1 \%$ in the fourth quarter of 2019 to 32 and $30.1 \%$ in the first quarter of 2020, respectively. Also, in Nigeria, reports show that the unemployment rate increased from $23.1 \%$ in the third quarter of 2018 to $27.1 \%$, as against $34.9 \%$ among youth in the age bracket $15-34$, in the second quarter of 2020 . Nonetheless, the average headline deficit has been projected to expand by $1.6 \%$ points of GDP in oil-exporting countries. Therefore, in conclusion, while debt is increasing and COVID-19 is threatening, sustainable development is feasible through inclusive growth, improved life expectancy and more jobs (employment) in SSA.

The findings, however, bear some policy implications. One, given that capital formation propels growth inclusiveness and life expectancy, governments across countries in SSA should strive more to build the sock of basic facilities like hospitals, schools, bridges, rails, airports, and roads. If these facilities are made available, economic activities will be facilitated, while enhanced output expansion will result in the gains accruing to everyone, including the poor, in society. Two, as entrepreneurship causes inclusive growth, it implies that the more entrepreneurs raised in SSA, the more inclusive the growth will be. As such, SSA countries should prioritize the fostering of new entrepreneurship, as well as support the existing ones through business-enhancing policies in order to make growth more inclusive in the region. Third, merchandise trade boosting growth inclusiveness and employment implies that merchandise exports overwhelm imports. Therefore, efforts should be geared towards facilitating the export of goods and services to generate more employment and inclusive growth in the region. Four, as agriculture value added is found to drive growth inclusiveness and employment, it points to the fact that agriculture is still the major employer of labour in SSA. Thus, relevant authorities should promote agricultural activities by supporting farmers and encouraging unemployed people, especially youths, to embrace setting up households farms and small and medium-scale enterprises for self-employment and food production across countries in the region. Five, given that import setbacks, growth inclusiveness and employment, regional governments should formulate policies that will encourage domestic production of certain goods that constitute part of the country's imports. For example, in the form of an import substitution strategy, countries can start producing light manufactures like shoes, furniture, wire cables, and food such as rice that take a large share of import bills. If countries do these, more jobs will be created with growth inclusiveness.

Sixth, external debt is reported to impact growth inclusiveness negatively. This implies that the more foreign debt liabilities, the less 
inclusive growth in SSA. To achieve growth inclusion, economies in the region should reduce the stock of their external debts by calling for outright debt cancellation or forgiveness. If debts are cancelled, it will afford SSA countries the leverage to commit financial resources to growth-enhancing activities rather than to debt repayments. Seven and lastly, as population growth negatively affects growth inclusiveness, life expectancy, and employment, it reflects the challenge confronting SSA countries in improving the living standard of people in the region. Although some schools of thought assert that population growth is desirable in many developing countries and regions, the issue of low per capita income, food insecurity and poverty make a rethink worthwhile. Accordingly, policies that can help control and empower population growth are in daring need across SSA countries. For example, the rising population can be productive through skills training and acquisition, apprenticeship, and farming. When a significant percentage of the SSA population is empowered through skill acquisition and financial support, the region will be better off with more employed people, increased output, and improved welfare.

\section{Declaration of conflicting interests}

The author(s) declared no potential conflicts of interest with respect to the research, authorship, and/or publication of this article.

\section{References}

Adegboye, E. (2018). Entrepreneurship - A pathway to sustainable development in Africa. In The Andela Way. https://medium.com/the-andela-way/entrepreneurship-apathway-to-sustainabledevelopment-in-africa-971b6498fd4

African Development Bank. (2013). Recognizing Africa's informal sector. https://blogs.afdb.org/afdb-championing-inclusive-growth-across-

africa/post/recognizing-africas-informal-sector-11645

African Development Bank. (2020). African economic outlook 2020: Developing Africa's workforce for the future.https:/www.afdb.org/en/documents/african-economicoutlook-2020

African Union. (2014). Agenda 2063: The Africa we want. Second Edition, Popular Version. http://archive.au.int/assets/images/agenda2063.pdf

Arellano, M., \& Bover, O. (1995). Another look at the instrumental variables estimation of error-components models. Journal of Econometrics,68, 29-51. https://doi.org/10.1016/0304-4076(94)01642-d

Balogun, A. (2016). Infrastructure development in Nigeria: Better late than never. Advisory Outlook: PricewaterhouseCoopers Ltd https://www.pwc.com/ng/en/assets/pdf/infrastructure-development-in-nigeria.pdf 
\begin{tabular}{l|l||l} 
Management \& Economics Research Journal & Vol. 3 No. $2(2021)$ & pp. 104-134 \\
\hline
\end{tabular}

Baltagi, B. H. (2008). Econometric analysis of panel data. 6th Edition, Chichester: Wiley. Baqaee, D., Farhi, E., Mina, M., \& Stock, J. H. (2020). Policies for a second wave. BPEA Conference Draft, June 25, Brooking Papers on Economic Activity. https://www.brookings.edu/wp-content/uploads/2020/06/Baqaee-et-al-conferencedraft.pdf

Barrero, J.M., Bloom, N., \& Davis, S.J. (2020). COVID-19 is also a reallocation shock. Brookings Papers on Economic Activity2020(2), 329-383. https://papers.ssrn.com/sol3/papers.cfm?abstractid=3592953

Barro, R.J. (1991). Economic growth in a cross section of countries. The Quarterly Journal of Economics, 106(2), 407-443.

Bitler, M.P., Hoynes, H.W., \& Schanzenbach, D.W. (2020). The social safety net in the wake of covid-19. Brookings Papers on Economic Activity2020(2), 119-158. https://doi.org/10.1353/eca.2020.0008

Blundell, R., \& Bond, S. (1998). Initial conditions and moment restrictions in dynamic panel data models. Journal of Econometrics,87, 115143.https://doi.org/10.1016/s0304-4076(98)00009-8

Catholic Agency for Overseas Development [CAFOD]. (2014). What is "inclusive growth"? CAFOD Discussion Paper (Full Version). www.cafod.org.uk/inclusive

Cecchetti, S. G., Mohanty, M. S., \& Zampolli, F. (2010). The future of public debt: Prospects and implications.BIS Working Papers No. 300, Basel: Bank for International Settlements.

Collier, P. (2007). The bottom billion: Why the poorest countries are failing and what can be done about it. Oxford: Oxford University Press.

Delong, J.B., \&Summers, L.H. (2012). Fiscal policy in a depressed economy. Brookings Papers on Economic Activity,2012(1), 233-297. https://doi.org/10.1353/eca.2012.0000

Duraiappah, A.K. (2015). Sustained inclusive growth re-examined. A contribution of IHDP, the International Human Dimension Programme on global environmental change of ICSU, the International Council for Science, and UNU, the United Nations University.

Economic Commission for Africa (2017). Inclusive and sustainable development in Arica: Institutional arrangements for implementing the 2030 agenda and 2063 agenda. Addis Ababa: Economic Commission for Africa.

Economic Commission for Africa. (2020). Covid-19 in Africa: Protecting lives and economies. Addis Ababa: ECA Printing and Publishing Unit. https://doi.org/10.18356/77f486e5-en

Filmer, D., \& Fox, L. (2014). Youth employment in sub-Saharan Africa. Africa DevelopmentSeries.Washington, DC: World Bank. https://doi.org/10.1596/978-14648-0107-5.

Gandhi, D., \& Golubski, C. (2020). Africa in the news: African governments, multilaterals address covid-19 emergency, debt relief.https://www.brookings.edu/blog/africa-infocus/2020/04/18/africa-in-the-news-african-governments-and-multilateralsaddress-covid-19-emergency-debt-relief/ 
Goldberg, P.K., \& Reed T. (2020). The effects of the coronavirus pandemic in emerging markets and developing economies: An optimistic preliminary account. BPEA Conference Draft, June 25, Brooking Papers on Economic Activity. https://www.brookings.edu/wp-content/uploads/2020/06/SU20_S3_Goldberg-

Reed_final-paper.pdf

Golubski, C., Kanos, D., \& Treacy, M. (2020). Africa in the news: Covid-19, financial assistance, and political updates from Malawi, Burundi, and Rwanda. https://www.brookings.edu/blog/africa-in-focus/2020/06/27/africa-in-the-newscovid-19-financial-assistance-and-political-updates-from-malawi-burundi-andrwanda/

Greene, W. H. (2011). Econometric analysis. $7^{\text {th }}$ Edition. Pearson Education: New York University.

Han, J., Meyer, B. D., \& Sullivan, J. X. (2020). Income and Poverty in the COVID-19 Pandemic. Brookings Papers on Economic Activity2020(2). https://doi.org/10.1353/eca.2020.0007

Harbi, S. E., Grolleau, G., \& Bekir, I. (2011). Entrepreneurship and growth: What causes what? Advances in the study of entrepreneurship, Innovation, and Economic Growth, 22, 73-91. https://doi.org/10.1108/s1048-4736(2011)0000022007

International Monetary Fund [IMF]. (2020a). Regional economic outlook: Sub-Saharan Africa: Covid-19: An unprecedented threat to development. Washington DC: IMF. https://doi.org/10.5089/9781513536835.086

International Monetary Fund. (2020b). Fiscal monitor: Policies to support people during the covid-19 pandemic. Washington DC: IMF. https://doi.org/10.5089/9781616352486.089

International Monetary Fund. (2020c). Regional economic outlook June 2020 update: SubSaharan Africa: A cautious reopening. Washington DC: IMF. https://doi.org/10.5089/9781513536835.086

Judson, R. A., \& Owen. A. L. (1999). Estimating dynamic panel data models: A guide for macroeconomists. Economic Letters, 65, 9-15. https://doi.org/10.1016/s01651765(99)00130-5

Kolawole, B.O. (2016). Government spending and inclusive-growth relationship in Nigeria: An empirical investigation. Zagreb International Review of Economics \& Business, 9(2), 33-56. https://hrcak.srce.hr/file/248913

Kumar, M.S., \& Woo, J. (2010). Public debt and growth. IMF Working Paper 10/174, Washington, DC: IMF.

Mahler, D.G., Lakner, C., Aguilar, R.A.C., \& Wu, H. (2020). Updated estimates of the impact of covid-19 on global poverty. https://blogs.worldbank.org/opendata/updated-estimates-impact-covid-19-globalpoverty

National Bureau of Statistics (2020). Key statistics:

Unemployment.www.nigerianstat.gov.ng

Ncube, M., Lufumpa, C.L., \& Kararach, G. (2017). Introduction: Infrastructure in African development. In Ncube, M. \& Lufumpa, C.L. (eds.), Infrastructure in Africa: Lessons for Future Development, pp. 1-22. University of Bristol, UK: Policy 
\begin{tabular}{l|l|l} 
Management \& Economics Research Journal & Vol. 3 No. 2 (2021) & pp. 104-134 \\
\hline
\end{tabular}

Press. https://doi.org/10.2307/j.ctt1t88xmm.9

Nickell, S. J. (1981). Biases in dynamic models with fixed effects. Econometrica, 49, 1417-1426. https://doi.org/10.2307/1911408

Obonyo, R. (2016). Africa looks to its entrepreneurs. Africa Renewal, 30(1), 16-17. https://doi.org/10.18356/1f87a356-en

Okonjo-Iweala, N., Coulibaly, B.S., Thiam, T., Kaberuka, D., Songwa, V., Masiyiwa, S., Mushikiwabo, L., \& Duarte, C. (2020a). Africa needs debt relief to fight covid-19. https://www.brookings.edu/opinions/africa-needs-debt-relief-to-fightcovid-19/.

Okonjo-Iweala, N., Coulibaly, B. S., Thiam, T., Kaberuka, D., Songwa, V., Masiyiwa, S., Mushikiwabo, L., \& Manual, T. (2020b). Covid-19 and debt standstill for

Africa: The g20's action is an important first step that must be complemented, scaled up, and broadened. https://www.brookings.edu/blog/africa-infocus/2020/04/18/covid-19-and-debt-standstill-for-africa-the-g-20s-action-is-animportant-first-step-that-must-be-complemented-scaled-up-and-broadened/.

Olubusoye, O. E., Salisu, A. A., \& Olofin, S.O. (2016). Applied panel data analysis, (Vol.1). Centre for Econometric and Allied Research (CEAR), Ibadan: Ibadan University Press.

Oostuizen, M., \& Cassim, A. (2016). Informality and inclusive growth in sub-Saharan Africa. ELLA Regional Evidence Papers, Development Policy Research Unit, University of Cape Town, South Africa. http://ella.practicalaction.org/knowledgeregional/informality-and-inclusive-growth-in-sub-saharan-africa/

Organization for Economic Co-operation and Development [OECD]/Food and Agriculture Organization [FAO] (2016). Agriculture in sub-Saharan Africa: Prospects and challenges for the next decade. In OECD-FAO Agricultural Outlook 2016-2025. https://doi.org/10.1787/agr_outlook-2016-5-en

Organization for Economic Co-operation and Development [OECD] (2018). The framework for policy action on inclusive growth. Meeting of the OECD Council at ministerial level. http://www.oecd.org/mcm/documents/C-MIN-2018-5-EN.pdf

Oyinlola, M. A., Adedeji, A. A., Bolarinwa, M.O., \& Olabisi, N. (2020). Governance, domestic resource mobilization, and inclusive growth in sub-Saharan Africa. Economic Analysis and Policy,65, 68-88.https://doi.org/10.1016/j.eap.2019.11.006

Reynolds, P. D., William, D., Bygrave, E.A., Larry, W.C., \& Michael, H. (2000). Global entrepreneurship monitor: 2000 executive report. Wellesley, MA/London: Babson College/London Business School.

Reynolds, P. D., William, D., Bygrave, E. A., Larry, W.C., \& Michael, H. (2002). Global entrepreneurship monitor: 2002 executive report. Wellesley, MA/London: Babson College/London Business School.

Secon, H. (2020). A comprehensive timeline of the new coronavirus pandemic, from China's first covid-19 case to the present. https://www.pulse.com.gh/bi/tech/acomprehensive-timeline-of-the-new-coronavirus-pandemic-from-chinasfirst-covid-19/sbb9e4z.

Srinivasu, B., \& Rao, S. (2013). Infrastructure development and economic growth: Prospects and perspective. Journal of Business Management \& Social Sciences 
Research, 2(1), 81-91.

Stam, E. (2008). Entrepreneurship and innovation policy. In Nooteboom, B., \& Stam, E. (eds.), Micro-Foundations for Innovation Policy. Amsterdam and Chicago: Amsterdam University Press and Chicago University Press .https://doi.org/10.1515/9789048501304

Suryanarayana, M. H. (2013). Inclusive growth: A sustainable perspective. Indira Gandhi Institute of Development Research, United Nations Development Programme, India.

Thorbecke, E. (2014). The structural anatomy and institutional architecture of inclusive growth in sub-Saharan Africa. WIDER Working Paper, 041, United Nations University, UNU-WIDER. https://doi.org/10.35188/unu-wider/2014/762-2

Todaro, M. P., \& Smith, S. C. (2003). Economic development. Eight Edition. Delhi: Pearson Education.

Toussaint, B. (2019). World bank: Sub-Saharan economic growth remains slower than expected.https://africa.cgtn.com/2019/04/08/world-bank-sub-saharan-economicgrowth-remains-slower-than-expected/

Trading Economics. (2020). Angola/South Africa unemployment rate. https://radingeconomics.com/angola/south-africa/unemployment-rate

United Nations. (2015). Transforming our world: The 2030 agenda for sustainabledevelopment.https://doi.org/10.1891/9780826190123.ap02

United Nations Conference on Trade and Development [UNCTAD]. (2005). Entrepreneurship and economic development: The Empretec showcase. English only. https://unctad.org/en/docs/webiteteb20043_en.pdf

United Nations Development Programme [UNDP] (2017). Strategy for inclusive and sustainable

growth.http:/www.undp.org/content/dam/undp/library/Poverty\%20Reduction/UN DPs\%20Inclusive\%20and\%20Sustainable\%20Growth-final.pdf

Vellala, P. S., Madala, M. K., \& Chhattopadhyay. (2014). A theoretical model for inclusive economic growth in India context. International Journal of Humanities and Social Science, 4(13), 229-235.

Whajah, J., Bokpin, G.A., \& Kuttu, S. (2019). Government size, public debt, and inclusive growth in Africa. Research in International Business and Finance, 49, 225-240. https://doi.org/10.1016/j.ribaf.2019.03.008

World Bank. (2007). World development report 2008: Agriculture and development. Washington DC: World Bank. https://doi.org/10.1596/978-0-8213-7297-5.

World Bank. (2019). Growth in sub-Saharan Africa remains below three percent three years after crisis. Press Release. https:/www.worldbank.org/en/news/pressrelease/2019/04/08/growth-in-sub-saharan-africa-remains-below-three-percentthree-years-after-crisis

World Bank. (2020a). The global economic outlook during the covid-19 pandemic: A changed world. Washington DC: World

Bank.https:/www.worldbank.org/en/news/feature/2020/06/08/the-globaleconomic-outlook-during-the-covid-19-pandemic-a-changed-world

World Bank. (2020b). World development indicators. Washington DC: World 
\begin{tabular}{l|l|l} 
Management \& Economics Research Journal & Vol. 3 No. 2 (2021) & pp. 104-134 \\
\hline
\end{tabular}

Bank.https://www.worldbank.org/en/region/afr/publication/africa-human-capitalplan

World Economic Forum. (2017). The inclusive growth and development report 2017.http://www3.weforum.org/docs/WEF_Forum_IncGrwth_2017.pdf

World Economic Forum. (2018). The inclusive development index 2018 summary and data highlights.http://www3.weforum.org/docs/WEF_Forum_IncGrwth_2018.pdf

Yalnizyan, A., \& Johal, S. (2018). Race to the top: Inclusive growth is the new growth model.https://www.theglobeandmail.com/business/commentary/article-race-to-thetop-inclusive-growth-is-the-new-growth-model/ 
Kolawole, B. O.

Debt, COVID-19 and Inclusive Growth for Sustainable Development in Sub-Saharan Africa

Appendix A:

COVID-19 confirmed cases and deaths in selected countries in SSA, March-August, 2020

\begin{tabular}{|c|c|c|c|c|c|c|c|c|c|c|c|c|}
\hline \multirow[b]{2}{*}{ Country } & \multicolumn{2}{|c|}{ March } & \multicolumn{2}{|l|}{ April } & \multicolumn{2}{|l|}{ May } & \multirow{2}{*}{$\begin{array}{c}\text { June } \\
\text { Cases }\end{array}$} & \multirow{2}{*}{\multicolumn{2}{|c|}{$\begin{array}{c}\text { July } \\
\text { Death Cases }\end{array}$}} & \multicolumn{3}{|c|}{ August } \\
\hline & Cases & Death & Cases & Death & Cases & Death & & & & Death & Cases & Death \\
\hline Angola & 7 & 2 & 27 & 2 & 86 & 4 & 284 & 13 & 1148 & 52 & 2654 & 108 \\
\hline Benin & 9 & 0 & 64 & 1 & 232 & 3 & 1199 & 21 & 1805 & 36 & 2145 & 40 \\
\hline Botswana & 4 & 1 & 23 & 1 & 38 & 1 & 227 & 1 & 804 & 2 & 1724 & 6 \\
\hline Burkina Faso & 261 & 14 & 645 & 43 & 847 & 53 & 962 & 53 & 1106 & 53 & 1370 & 55 \\
\hline Burundi & 2 & 0 & 11 & 1 & 63 & 1 & 170 & 1 & 395 & 1 & 445 & 1 \\
\hline Cameroon & 233 & 6 & 1832 & 61 & 6143 & 197 & 12592 & 313 & 17255 & 391 & 14409 & 414 \\
\hline Cape Verde & 6 & 1 & 122 & 1 & 458 & 4 & 1267 & 15 & 2451 & 23 & 3884 & 40 \\
\hline CAR & 3 & 0 & 64 & 0 & 1011 & 2 & 3745 & 47 & 4608 & 59 & 4711 & 62 \\
\hline Chad & 7 & 0 & 73 & 5 & 778 & 65 & 866 & 74 & 936 & 75 & 1013 & 77 \\
\hline Comoros & - & - & 1 & 0 & 106 & 2 & 303 & 7 & 378 & 7 & 423 & 7 \\
\hline DR Congo & 109 & 9 & 572 & 31 & 3195 & 72 & 7122 & 175 & 9084 & 215 & 10104 & 259 \\
\hline Congo Rep. & 19 & 0 & 220 & 9 & 611 & 20 & 1087 & 37 & 3200 & 54 & 3979 & 78 \\
\hline Cote D'Ivoire & 179 & 1 & 1275 & 14 & 2833 & 33 & 9499 & 68 & 16047 & 102 & 18067 & 117 \\
\hline Eq. Guinea & 15 & 0 & 315 & 1 & 1306 & 12 & 2001 & 32 & 4821 & 83 & 4941 & 83 \\
\hline Ethiopia & 29 & 0 & 133 & 3 & 1257 & 12 & 5846 & 103 & 17999 & 284 & 52131 & 809 \\
\hline Eswatini & 9 & 0 & 106 & 1 & 285 & 2 & 812 & 11 & 2648 & 41 & 4577 & 91 \\
\hline Gabon & 18 & 1 & 276 & 3 & 2655 & 17 & 5394 & 42 & 7352 & 49 & 8533 & 53 \\
\hline Gambia & 4 & 1 & 12 & 1 & 25 & 1 & 49 & 2 & 498 & 9 & 3029 & 96 \\
\hline Ghana & 195 & 5 & 2074 & 17 & 8070 & 36 & 17741 & 112 & 35501 & 182 & 44298 & 276 \\
\hline Guinea & 30 & 0 & 1405 & 7 & 3706 & 23 & 5391 & 33 & 7308 & 46 & 9409 & 59 \\
\hline Guinea Bissau & 8 & 0 & 205 & 1 & 1256 & 8 & 1654 & 24 & 1981 & 26 & 2205 & 34 \\
\hline Kenya & 81 & 1 & 411 & 21 & 2021 & 69 & 6673 & 149 & 21363 & 364 & 34201 & 577 \\
\hline Lesotho & - & - & - & - & 2 & 0 & 27 & 0 & 702 & 14 & 1085 & 31 \\
\hline Liberia & 6 & 0 & 152 & 18 & 296 & 27 & 804 & 37 & 1189 & 75 & 1304 & 82 \\
\hline
\end{tabular}

Source: Author's compilation from www.worldometers.info/coronavirus/ 


\section{Appendix B:}

COVID-19 confirmed cases and deaths in selected countries in SSA, March-August, 2020

\begin{tabular}{lllllllllllll}
\hline & \multicolumn{3}{c}{ March } & \multicolumn{3}{c}{ April } & \multicolumn{1}{c}{ May } & \multicolumn{3}{c}{ June } & \multicolumn{3}{c}{ July } & \multicolumn{3}{c}{ August } \\
Country & Cases & Death Cases & DeathCases & Death & Cases & Death Cases & Death Cases & Death \\
\hline Madagascar & 57 & 0 & 132 & 0 & 826 & 6 & 2303 & 22 & 11273 & 107 & 14957 & 195 \\
Malawi & - & - & 37 & 3 & 284 & 4 & 1265 & 16 & 4078 & 114 & 5566 & 175 \\
Mali & 31 & 3 & 508 & 26 & 1315 & 78 & 2181 & 116 & 2535 & 124 & 2776 & 126 \\
Mauritius & 158 & 5 & 332 & 10 & 335 & 10 & 341 & 10 & 344 & 10 & 356 & 10 \\
Mozambique & 10 & 0 & 76 & 0 & 254 & 2 & 903 & 6 & 1864 & 12 & 4039 & 23 \\
Namibia & 14 & 0 & 16 & 0 & 25 & 0 & 257 & 0 & 2129 & 10 & 7692 & 81 \\
Niger & 34 & 3 & 719 & 32 & 958 & 64 & 1075 & 67 & 1134 & 69 & 1176 & 69 \\
Nigeria & 151 & 2 & 1932 & 58 & 10162 & 287 & 25694 & 590 & 43151 & 879 & 54008 & 1013 \\
Rwanda & 75 & 0 & 243 & 0 & 370 & 1 & 1025 & 2 & 2022 & 5 & 4063 & 16 \\
Sao Tome & - & - & 16 & 1 & 483 & 12 & 714 & 13 & 871 & 15 & 896 & 15 \\
Senegal & 190 & 1 & 1024 & 9 & 3739 & 42 & 6925 & 116 & 10284 & 209 & 13655 & 284 \\
Sierra Leone & 1 & 0 & 136 & 7 & 865 & 46 & 1462 & 60 & 1823 & 67 & 2022 & 70 \\
South Africa & 1380 & 5 & 5647 & 103 & 34357 & 705 & 151209 & 2657 & 493183 & 8005 & 627041 & 14149 \\
Sudan & 7 & 2 & 442 & 31 & 5026 & 286 & 9257 & 572 & 11644 & 746 & 13189 & 823 \\
Tanzania & 20 & 1 & 480 & 16 & 509 & 21 & 509 & 21 & 509 & 21 & 509 & 21 \\
Togo & 36 & 2 & 123 & 9 & 442 & 13 & 650 & 14 & 941 & 19 & 1400 & 28 \\
Uganda & 7 & 2 & 83 & 0 & 457 & 0 & 893 & 0 & 1176 & 4 & 3037 & 32 \\
Zambia & 36 & 0 & 109 & 3 & 1089 & 7 & 1632 & 30 & 6228 & 165 & 12097 & 288 \\
Zimbabwe & 8 & 1 & 40 & 4 & 178 & 4 & 591 & 7 & 3169 & 67 & 6497 & 202 \\
\hline
\end{tabular}

Source: Author's compilation from www.worldometers.info/coronavirus 
Kolawole, B. O.

Debt, COVID-19 and Inclusive Growth for Sustainable Development in Sub-Saharan Africa

Appendix C:

COVID-19 confirmed cases and deaths in selected countries in SSA, September-December, 2020

\begin{tabular}{|c|c|c|c|c|c|c|c|c|}
\hline \multirow[b]{2}{*}{ Country } & \multicolumn{2}{|c|}{ September } & \multicolumn{2}{|c|}{ October } & \multicolumn{2}{|c|}{ November } & \multicolumn{2}{|c|}{ December } \\
\hline & Cases & Death & Cases & Death & Cases & Death & Cases & Death \\
\hline Angola & 4972 & 183 & 10805 & 284 & 15139 & 348 & 17553 & 405 \\
\hline Benin & 2357 & 41 & 2683 & 41 & 3015 & 43 & 3251 & 44 \\
\hline Botswana & 3172 & 16 & 6642 & 24 & 10742 & 34 & 14805 & 42 \\
\hline Burkina Faso & 2056 & 58 & 2500 & 67 & 2886 & 68 & 6707 & 85 \\
\hline Burundi & 508 & 1 & 589 & 1 & 689 & 1 & 818 & 10 \\
\hline Cameroon & 20838 & 418 & 21793 & 426 & 24445 & 437 & 26277 & 448 \\
\hline Cape Verde & 6024 & 60 & 8793 & 95 & 10761 & 105 & 11840 & 113 \\
\hline CAR & 4829 & 62 & 4866 & 62 & 4913 & 63 & 4963 & 63 \\
\hline Chad & 1200 & 85 & 1498 & 98 & 1688 & 101 & 2113 & 104 \\
\hline Comoros & 479 & 7 & 545 & 7 & 613 & 7 & 823 & 10 \\
\hline DR Congo & 10685 & 272 & 11306 & 307 & 12772 & 333 & 17658 & 591 \\
\hline Congo Rep. & 5089 & 89 & 5290 & 92 & 5774 & 94 & 7107 & 108 \\
\hline Cote D'Ivoire & 19724 & 120 & 20716 & 126 & 21331 & 132 & 22490 & 137 \\
\hline Eq. Guinea & 5030 & 83 & 5088 & 83 & 5153 & 85 & 5277 & 86 \\
\hline Ethiopia & 75368 & 1198 & 96169 & 1469 & 110074 & 1706 & 124269 & 1923 \\
\hline Eswatini & 5482 & 109 & 5917 & 117 & 6419 & 122 & 9358 & 205 \\
\hline Gabon & 8766 & 54 & 9868 & 55 & 9214 & 60 & 9571 & 64 \\
\hline Gambia & 3584 & 113 & 3672 & 119 & 3742 & 123 & 3797 & 124 \\
\hline Ghana & 46656 & 301 & 48124 & 320 & 51667 & 323 & 54771 & 335 \\
\hline Guinea & 10652 & 66 & 12150 & 73 & 13199 & 76 & 13738 & 81 \\
\hline Guinea Bissau & 2324 & 39 & 2413 & 41 & 2441 & 44 & 2452 & 45 \\
\hline Kenya & 38713 & 711 & 55877 & 1013 & 84169 & 1474 & 96614 & 1681 \\
\hline Lesotho & 1639 & 38 & 1953 & 44 & 2137 & 44 & 3206 & 51 \\
\hline Liberia & 1343 & 82 & 1426 & 82 & 1595 & 83 & 1779 & 83 \\
\hline
\end{tabular}

Source: Author's compilation from www.worldometers.info/coronavirus 


\section{Appendix D:}

COVID-19 confirmed cases and deaths in selected countries in SSA, SeptemberDecember, 2020

\begin{tabular}{lllllllll}
\hline & \multicolumn{3}{l}{ September } & October & \multicolumn{3}{l}{ November } & \multicolumn{2}{l}{ December } \\
Country & Cases & Death & Cases & Death & Cases & Death & Cases & Death \\
\hline Madagascar & 16454 & 232 & 17111 & 244 & 17341 & 251 & 17714 & 261 \\
Malawi & 5773 & 179 & 5932 & 184 & 6028 & 185 & 6583 & 189 \\
Mali & 3118 & 131 & 3565 & 136 & 4710 & 156 & 7090 & 269 \\
Mauritius & 381 & 10 & 441 & 10 & 504 & 10 & 527 & 10 \\
Mozambique & 8728 & 61 & 12988 & 93 & 15770 & 131 & 18794 & 167 \\
Namibia & 11373 & 123 & 12988 & 133 & 14380 & 151 & 23941 & 205 \\
Niger & 1197 & 69 & 1220 & 69 & 1548 & 72 & 3323 & 104 \\
Nigeria & 58848 & 1112 & 62853 & 1144 & 67557 & 1173 & 87607 & 1289 \\
Rwanda & 4840 & 29 & 5137 & 35 & 5934 & 49 & 8383 & 92 \\
Sao Tome & 911 & 15 & 945 & 16 & 996 & 17 & 1022 & 17 \\
Senegal & 15019 & 311 & 15630 & 325 & 16107 & 333 & 19364 & 410 \\
Sierra Leone & 2231 & 72 & 2366 & 74 & 2412 & 74 & 2635 & 76 \\
South Africa & 674339 & 16734 & 725452 & 19276 & 790004 & 21535 & 1057161 & 28469 \\
Sudan & 13640 & 836 & 13804 & 837 & 17810 & 1249 & 23316 & 1468 \\
Tanzania & 509 & 21 & 509 & 21 & 509 & 21 & 509 & 21 \\
Togo & 1784 & 48 & 2331 & 57 & 2974 & 64 & 3633 & 68 \\
Uganda & 8287 & 75 & 12743 & 112 & 20459 & 205 & 35511 & 265 \\
Zambia & 14802 & 333 & 16480 & 349 & 17665 & 357 & 20997 & 390 \\
Zimbabwe & 7838 & 228 & 8367 & 243 & 10034 & 277 & 13867 & 363 \\
\hline
\end{tabular}

Source: Author's compilation from www.worldometers.info/coronavirus 